ppi $201502 Z U 4645$

Esta publicación cientifica en formato digital es continuidad de la revista impresa ISSN-Versión Impresa 0798-1406 / ISSN-Versión on line 2542-3185Depósito legal pp

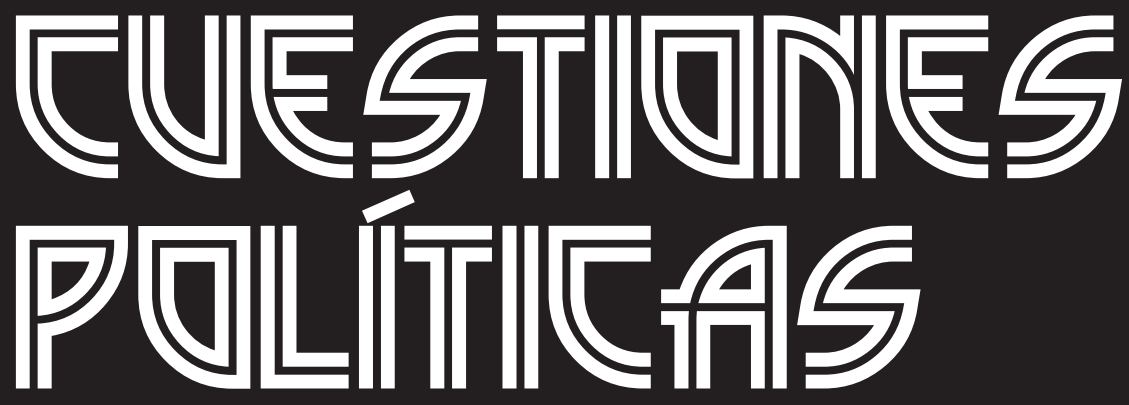

Instituto de Estudios Políticos y Derecho Público "Dr. Humberto J. La Roche' de la Facultad de Ciencias Jurídicas y Políticas de la Universidad del Zulia Maracaibo, Venezuela
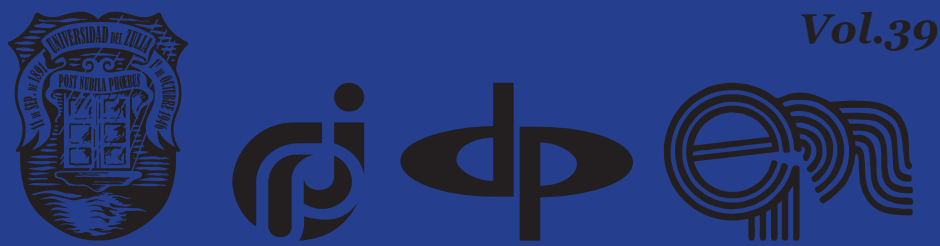


\title{
Egyptian-Israeli Relations during the Government of Mohamed Morsi (2012-2013)
}

\author{
DOI: https://doi.org/10.46398/cuestpol.3968.12
}

\begin{abstract}
Ayrat Halitovich Tuhvatullin * Vitaly Anatolievich Epshteyn ** Pavel Vladimirovich Pichygin *** Alina Petrovna Sultanova ****
\end{abstract}

\section{Abstract}

The article highlights the details of the foreign policy of the Arab Republic of Egypt and its impact on the regional security of the state of Israel in between 2012-2013. After the Islamists came to power, they began to dominate expectations that the political force led by Mohamed Morsi would initiate an active anti-Israel policy, however, with active anti-Semitic rhetoric, the "Muslim brotherhood" was able to maintain peaceful relations with Israel. The purpose of this study was to characterize the relationship between M. Morsi's government and the state of Israel during the period 2012 to 2013while revealing the impact of various factors on the preservation of peace in the region, especially in the face of the conflict situation that intensified in neigh boring countries such as Libya and Syria. The main approaches to the study of the problem under consideration were analytical method and content analysis. It is concluded that the article can also contribute to the study of the history of the Middle East within the framework of Arab-Israeli relations against the deterioration of the political situation and the strengthening of religious radicalism in the region.

* Kazan Federal University, Candidate of Historical Sciences, Associate Professor, Department of Historical and Social Studies Education, Institute of International Relations. ORCID ID: http://orcid. org/oooo-0oo1-6042-5711. Email: tayrat@mail.ru

** Russian Presidential Academy of National Economy and Public Administration (RANEPA, Moscow), PhD in Sociology, Associate Professor, Department of World Economy and International Relations, Institute of Business and Business Administration. ORCID ID: http://orcid.org/oooo-0001-73083351. Email: epshteinv@gmail.com

*** Russian Presidential Academy of National Economy and Public Administration (RANEPA, Moscow), Master student of the program "International Relations and Integration Processes in Eurasia", Faculty of International Relations, Institute of Business and Business Administration. ORCID ID: https:// orcid.org/oooo-0001-9554-5772. Email: pichuginpavel96@gmail.com

**** Kazan National Research Technical University named after A.N. Tupolev - KAI (Kazan), PhD, Associate Professor in Comparative-historical, typological, and contrastive linguistics, Department of foreign languages, Russian, and Russian as a foreign language. ORCID ID: https://orcid.org/ooooooo3-2723-4715. Email: alinasultanova@mail.ru 


\begin{abstract}
Ayrat Halitovich Tuhvatullin, Vitaly Anatolievich Epshteyn, Pavel Vladimirovich Pichygin y
Alina Petrovna Sultanova
Egyptian-Israeli Relations during the Government of Mohamed Morsi (2012-2013)
\end{abstract}

Keywords: Middle East; Arab-Israeli conflict; Egypt-Israel relationship; terrorism in Sinai; geopolitical studies.

\title{
Relaciones egipcio-israelies durante el gobierno de Mohamed Morsi (2012-2013)
}

\section{Resumen}

El artículo destaca los detalles de la política exterior dela República Árabe de Egipto y su impacto en la seguridad regional del estado de Israel entre 2012-2013. Después de que los islamistas llegaron al poder, comenzaron a dominar las expectativas de que la fuerza política encabezada por Mohamed Morsi iniciaría una política antiisraelí activa, sin embargo, con la retórica antisemita activa, la "hermandad musulmana" pudo mantener relaciones pacíficas con Israel. El propósito de este estudio fue caracterizar la relación entre el gobierno de M. Morsi y el estado de Israel durante el período de 2012 a 2013 y, al mismo tiempo, revelar el impacto de diversos factores en la preservación de la paz en la región, especialmente frente a la situación de conflicto que se intensificó en los países vecinos como Libia y Siria. Los principales enfoques para el estudio del problema en consideración fueron el método analítico y el análisis de contenido. Se concluye que el artículo puede contribuir además al estudio de la historia de Oriente Medio en el marco de las relaciones árabe-israelíes contra el deterioro de la situación política y el fortalecimiento del radicalismo religioso en la región.

Palabras clave: Oriente Medio; conflicto árabe-israelí; relación EgiptoIsrael; terrorismo en el Sinaí; estudios geopolíticos.

\section{Introduction}

After the Arab Spring events in 2011, Islamists came to power in the Arab Republic of Egypt (ARE). Hosni Mubarak, who had been in power since 1981, was stripped of all ranks and taken into custody; until June 2012, the country was being governed by the Supreme Council of the armed forces (SCAF), the former ruling National democratic party being dissolved and outlawed, and its leaders and activists being removed from power. At the election to the legislative authority, held from November 2011 until February 2012, the Muslim Brotherhood won $47.2 \%$ of the lower house seats and $56 \%$ of upper house seats in the Egyptian Parliament.

Undoubtedly, one of the main reasons for the election victory, won by the Democratic Alliance headed by the Freedom and Justice Party (FJP) of 
the political wing of the Muslim Brotherhood (BM), was due to the absence of restrictions on the activities of the Islamic opposition that took place in the previous period.

The history of the "Muslim Brotherhood" movement in the late twentieth and early twenty-first centuries shows that at that time it was the dominant opposition force in the country with an original ideological platform, a welldeveloped and well-organized network, and a credible social support (The times of Israel, 2012).

After coming to power as an opposition to former President Hosni Mubarak (b. 1928), the FJP criticized the former government on many issues, and the most acute criticism was on the issue of the gas contract between Egypt and Israel. The FJP claimed that the government was seeking to "make Egypt subservient to Israel" because of gas exports at below-market prices $^{5}$ (Election program: The Freedom and Justice Party, 2011).

There were a number of concerns and open questions about the new government:

- How Egypt will build relationships with the world leading powers.

- How Egypt will manage domestic security issues.

- What the future cooperation with Israel will be like and whether it will be possible.

- How Egypt will build relationships with the Islamic Republic of Iran in the conditions of cooperation with the Salafists (Haber and Ighani, 2013).

\section{Methods}

This article uses such research methods as content analysis and comparative institutional analysis. The purpose of content analysis is not just to describe the structural elements of the phenomenon under study but also to clarify the cause-and-effect relationships that underlie the prevalence, dynamics, and stability/instability of this phenomenon. Comparativeinstitutional analysis studies a set of factors that affect the object of research, identifying among them the main and secondary, temporary, and stable, explicit and latent (hidden), managed and unmanaged ones. These approaches help to reduce the subjectivity in the qualitative analysis process to obtain the information as the result of the study.

5 In 2005, the agreement on the supply of gas from Egypt to Israel was signed (for a period of 15 years). According to experts, the market price of gas was much higher, and that agreement was signed for political reasons. After 2011, deliveries stopped due to terrorists' constant attacks on the pipeline in the Sinai Peninsula. 
Ayrat Halitovich Tuhvatullin, Vitaly Anatolievich Epshteyn, Pavel Vladimirovich Pichygin y Alina Petrovna Sultanova

\section{Results and Discussion}

The government of the Muslim Brotherhood, which came to power as the result of the "color revolution", sought to support HAMAS, as well as to establish relations with Iran and Islamic fundamentalists, that is, with all those who denied the right of Israel to exist. In response, the government of Benjamin Netanyahu maintained ties with the Egyptian military, which had disagreements with the new political elite of Egypt. These contacts became more active during the period of Morsi's struggle for political power, as in an interview with the Forbes magazine in 2010, the latter described the Jews as a collection of "monkeys and pigs", (Behar, 2013) which naturally could not but cause discontent in Israeli society.

There was no official response from Israel, however, there were concerns in the United States about the future foreign policy of BM, and, consequently, there were suggestions of a possible threat to the freedom of passage of ships through the Suez Canal. After a warning from the United States to reduce financial aid, Morsi said that his words had been "taken out of context" (The New York Times, 2013).

In the video published by Middle East Media Research Institute (MEMRI) in 2010, he stated:

The Zionists have no right to the land of Palestine. There is no place for them in the land of Palestine. What they took in 1947-48 is looting, and what they are doing now is a continuation of this looting. In no case do we recognize their Green Line. The land of Palestine belongs to the Palestinians, not to the Zionists (The Times of Israel, 2013: s/p).

For that statement, Morsihad to justify himself again. During his visit to Germany in January 2013, he stated that his remarks had been taken out of the context again, insisting that they had been intended as a criticism of Israel's policy towards the Palestinians. Addressing reporters, Morsisaid, "[I] am not against the Jewish faith or the Jewish people. My comments were about the behavior that causes blood to be shed and innocent people to die" (The Times of Israel, 2013: s/p).

After becoming President of Egypt, Morsiattempted to maintain the position of an independent leader of the largest Arab country, using the anti-Semitic rhetoric once again, saying, "It is necessary to distinguish between Judaism and those who belong to it, and violent actions against defenseless Palestinians" (The New York Times, 2013).

Real foreign policy was different from the public rhetoric. Although Morsi acknowledged that he would comply with all international agreements of Egypt, implicitly referring to the agreement of Egypt with Israel at Camp David, however, on the other hand, he called for the restoration of relations with Tehran, stating the need to "change the balance" of Egypt's foreign policy (Ben Gedalyahu, 2012). 
The Israeli response was not long in coming; Israeli Prime Minister Benjamin Netanyahu launched a joint diplomatic process with Egypt to find common ground, saying: "we expect to build cooperation with the new government on the basis of our peace treaty" (Spencer, 2012: s/p) As an act of starting a new relationship, Morsi appointed a new Egyptian Ambassador to Israel, Atef Salem (The Times of Israel, 2012).

The act of appointing a new Ambassador had its own cause for concern. The letter of accreditation from the Egyptian President to his Israeli counterpart, Shimon Peres, was not received unambiguously in the Arab world. The text began with the words "Dear and great friend" and ended with the phrase "from a loyal friend of Mohammed Morsi". The letter contained Morsi's desire to develop close relations between the two countries (Alarabiya, 2012). A great number of high-ranking Egyptian officials and representatives of the "BM" claimed that the letter had been falsified, and M. Morsi initially denied sending the letter (The times of Israel, 2012). However, later, the presidential spokesperson, Yasser Ali, told the Egyptian state newspaper "Al-Ahram" that the letter was "100 percent correct" (The times of Israel, 2012).

It is worth noting that not everything was smooth inside the military elite of Egypt that anxiously expected to expand cooperation with HAMAS. The military that has always been part of the country's ruling elite, regarded the rapprochement with the group as a threat to national security. Within the Egyptian elite, there were thoughts that:

Instability and chaos in the Palestinian territory may flow into Egypt with particularly dangerous consequences in the Sinai. Since HAMAS has been a problem for a long time, the Gaza Strip being the main worry for the entire region, free movement between the Gaza Strip and Sinai would contribute to lawlessness, smuggling of fighters and weapons (Middle East, 2012: s/p).

That view was confirmed by the terrorist attack in August 2012 on the Egyptian-Israeli border. Attacking the border guards, Islamist militants killed fifteen Egyptian soldiers and captured armored vehicles. Later, they intended to cross the border and attack the Israeli boundary post. The Israeli defense Forces' counter-terrorism actions resulted in the killing of seven militants: four of them were killed on the Israeli side and three of them were killed on the territory of Egypt. HAMAS condemned the attack, however, the situation on the Peninsula deteriorated sharply (The Guardian, 2012).

Israel, which supported the democratic changes in Egypt, expected Morsi to start a real dialogue, but the beginning of contacts was not rosy, since the Prime Minister of the Palestinian authority, Ismail Haniyeh, and the former head of the HAMAS Political Bureau, Khaled Mashal, visited Cairo on September 17, 2012. The talks focused on security cooperation, lifting the blockade of the Gaza Strip, and creating a free trade zone in the 
Ayrat Halitovich Tuhvatullin, Vitaly Anatolievich Epshteyn, Pavel Vladimirovich Pichygin y Alina Petrovna Sultanova

border area between Egypt and the Gaza Strip. Perhaps, one of the goals of Khaled Mashal's visit to Cairo was to discuss further reconciliation between HAMAS and FATAH with the Egyptian intelligence leadership. However, judging by the extremely negative reaction of the head of the Palestinian authority, Mahmoud Abbas, to Ismail Haniyeh's trip to Cairo, it was somewhat premature to talk about an early reconciliation (The Times of Israel, 2012).

Moreover, according to some experts, the HAMAS leadership expressed the interest in separating the Gaza Strip from the West Bank and creating an independent state on its territory with the support of Egypt. However, those events could have added an additional complication to President M. Morsi's situation, because, in Washington, the possible strengthening of HAMAS would have been met with extreme disapproval, not to mention the creation of a new state within the borders of the Gaza Strip. In this regard, M. Morsi'sfurther policy in relations with HAMAS was more restrained, although, aimed at intensifying cooperation. The attempt to initiate a dialogue between HAMAS and FATAH was not successful; moreover, Egypt did not have a real material and technical opportunity to reduce the role of the United States and Israel in resolving the intra-Palestinian conflict.

On September 26, 2012, Morsi made a speech at the UN General Assembly, most of which was devoted to the Palestinian issue. "The first issue that the world must make efforts to resolve, on the basis of justice and dignity, is the Palestinian cause," Morsi said. Also, the Egyptian leader recalled the "sacred right of the Palestinians to their own state with its capital in Jerusalem" (Egypt: Speech by President Morsi to UN General Assembly, 2012: s/p).

\section{Summary}

Eric Trager, an expert on the "Muslim Brotherhood" issues at the Washington Institute for Near East policy, argued that the BM did seek to renegotiate the Camp David Accords, since every member of the organization was imbued with anti-Semitic and anti-Israeli hatred for the Treaty. Moreover, the ideological positions of the Muslim Brotherhood were principally incompatible with the preservation of the Egyptian-Israeli peace (Haber and Ighani, 2013).

Glen Segell, a research fellow at Tel Aviv Institute for National Security, argues that there were more changes in Egyptian-Israeli relations under Mohammed Morsi than Under G. Nasser, A. Sadat and H. Mubarak. ${ }^{6}$ The

6 Gamal Abdel Nasser (1918-1970) - President of Egypt (1956-1970), Muhammad Anwar el-Sadat (19181981) - President of Egypt (1970-1981), Muhammad HosniEl SayedMubarak (b. 1928) - President of Egypt (1981-2011) 
Russian researcher I. M. Mokhova also agrees about it, arguing that the preservation of the Camp David system and restraint towards Israel were largely due to Egypt's domestic realities (Mokhova, 2012).

On the other hand, the Russian researcher Sergey Starkin says that there emerged a radically new method of implementing foreign policy. The choice of the Islamic vector of development implied the development of relationships with the religious leaders of the region. As part of the change in Egypt's foreign policy agenda, the new course was aimed at moving away from "Mubarak's previous, too Pro-Western course, by expanding the number of foreign political partners" (Starkin, 2012: 165).

Attempts at rapprochement between Egypt and the Islamic Republic of Iran were also met with very mixed reactions. It was vital for the government of Mahmoud Ahmadinejad to find a regional ally to counter the blockade by the United States and Israel. Egypt saw its advantage in that, since the signing of the Camp David Accords (1982), Cairo has lost its role and importance among the Arab countries, moreover, it has lost the right of representation in the League of Arab States, among the founders of which was the Egyptian state. Mohammed Morsi sought to restore the country's position through negotiations with Iran, while maintaining established relations with Tehran's opponents. Therefore, at the first meeting in 30 years, only an agreement on expanding tourism was signed, and that allowed the speaker of the Iranian Parliament Ali Larijani to state: "For a long time, Egypt and Iran, as two large Muslim countries, have had close ties and playedthe key role in Islamic civilization" (The Washington Post, 2012: s/p).

Iranian President Mahmoud Ahmadinejad paid a return visit to Egypt only in February 2013, visiting, among other things, Al-Azhar University, which is considered the main religious and educational center in the Islamic world.

All of those steps taken by Cairo in the foreign policy arena could not but cause concern for Israel, whose leadership reacted with restraint to the counter-coup by the Egyptian military on July 3, 2013. Prime Minister Benjamin Netanyahu ordered that members of his Cabinet "should not make public statements or give interviews" on this issue. Israel's Minister for Transport Yisrael Katz said in an interview with Israel's Army Radio: 'This is an Egyptian issue; we have to worry about our own interests' (CBC News, 2013: s/p).

During the period of instability in the Arab Republic of Egypt, radical groups became active in the Sinai Peninsula. If, before the main problem for the stability of the region was the Bedouins, who used the border territories for smuggling goods, kidnapping and slave trade, then, due to the weakening of the centralauthority, the main threat was terrorists, and the 
Ayrat Halitovich Tuhvatullin, Vitaly Anatolievich Epshteyn, Pavel Vladimirovich Pichygin y Alina Petrovna Sultanova

Sinai Peninsula once again became a springboard for supplying the Gaza Strip. In this regard, for Mohammed Morsi, cooperation with the Israeli government did not lose its priority (Khizriyev, 2016).

Egypt acted as a mediator in the negotiation process between Israel and Palestine. The deal demonstrated the pragmatism of President Mohamed Morsi, who combined support for HAMAS with a desire to maintain peace with Israel. In the most critical days, demonstrating solidarity with HAMAS, President Morsi expelled the Israeli Ambassador from Cairo and sent the Egyptian Prime Minister to the Gaza Strip, but kept channels with representatives of the United States and Israel open to participate in the negotiation process (Haber and Ighani, 2013). The President of Egypt, with his diplomatic pressure, sought to achieve a ceasefire, though US Secretary of State Hillary Clinton had the last word. However, Israel, the United States and HAMAS appreciated the mediating role, played by the Islamic government of Egypt (The New York Times, 2012).

Quickly enough, M. Morsi had to switch to events inside the country, where demonstrations against the constitutional Declaration swept through all of the major cities. That is why Morsi's administration took the next step in the foreign policy field only in February 2013, when the smugglers tunnels were flooded, through which, according to the Egyptian authorities, weapons were transported for terrorists in North Sinai. The actions of the Morsi government against the tunnels demonstrated the priority of the national security issue inside the country. However, according to experts, the authorities unsuccessfully tried to solve domestic security problems with that foreign policy decision (The New York Times, 2013).

The attempts to completely block the tunnels were doomed to failure, and only the next regime led by Al-Sisi managed to resist the onslaught of terrorists in the North of the Peninsula by force. The researcher M. A. Sapronova speaks about the unresolved goals of domestic and foreign policy. President Morsi's tactics without a strategy had consequences not only on his career but also on the future of political Islamism in Egypt, which was supported by the country's population, but after a series of setbacks, approved of a military coup in 2013 (Sapronova, 2013).

President Morsi had to interrupt not only the participation in the GazaIsrael negotiation process, but also new meetings with European leaders. In 2013, Morsi focused on internal issues, but in June of the same year, he declared war on two countries - the Syrian Arab Republic and the Federal Democratic Republic of Ethiopia. First, he broke off relations with Syria and expressed a desire to send Egyptian military and volunteers to help the opposition overthrow Bashar al-Assad (Podtserob, 2017). Doing so, he violated Egypt's long - standing principle of non-interference in the military affairs of other Arab States, which had been developed due to the costly participation in the civil war in Yemen a decade earlier (Gafurov et 
al., 2019). Second, a security meeting chaired by Morsi raised the issue of participating in air strikes on the Grand Ethiopian Renaissance Dam ${ }^{7}$ to prevent the threat of a water crisis that might arise from the Nilewater decrease.

\section{Conclusions}

Thus, the period of Egyptian-Israeli relations in 2012-2013 cannot be called threatening to the security of the Jewish state. Having come to power with a reputation as an Islamic fundamentalist, anti-Semite and an ally of the Palestinians, Mohammed Morsi did not destroy the difficult relations that had been established for years between the Arab Republic of Egypt and the state of Israel.

The general security problem forced President Morsi to act in accordance with the national interests of Egypt, which, like Israel, had been repeatedly attacked by terrorists' groups that had taken refuge in the Sinai. In addition, according to the Camp David Accords, Cairo could only increase its military contingent in the Sinai Peninsula after consulting with Tel Aviv. Moreover, the Israeli government provided and continued to provide the operations of the Egyptian army with military support, which needed not only technical equipment but also information, received by the Israeli intelligence community.

An important factor in maintaining relations between the Arab Republic of Egypt and the state of Israel was the close relationship between the ruling Egyptian Muslim Brotherhood party and the Palestinians. Thanks to close contacts and trusting relations, Morsi could have claimed to be a mediator between the two irreconcilable rivals, reducing tensions in the Middle East, which in turn was in the interests of Cairo (Shagalov and Manina, 2016).

\section{Acknowledgements}

The work is performed according to the Russian Government Program of Competitive Growth of Kazan Federal University.

\section{Bibliographic References}

ALARABIYA. 2012. Morsi letter to Peres. Available online. In: http://www. alarabiya.net/articles/2012/10/18/244522.html. Consultation date: 08/02/2020.

7 The hydroelectric power station "Renaissance" (Hidase HEPS) is a large hydraulic structure on the territory of the Federal Democratic Republic of Ethiopia on the border with Sudan, located on the Blue Nile, a tributary of the Nile River. After commissioning, it should become the largest hydroelectric power station in Africa. 
Ayrat Halitovich Tuhvatullin, Vitaly Anatolievich Epshteyn, Pavel Vladimirovich Pichygin y Alina Petrovna Sultanova

AL-BAB.COM. 2012. Egypt: Speech by President Morsi to UN General Assembly. Available online. In: http://al-bab.com/documents-section/ egypt-speech-president-morsi-un-general-assembly-2012. Consultation date: $08 / 02 / 2020$.

BEHAR, Richard. 2013. News Flash: Jews Are 'Apes and Pigs.' So Why Is Egypt's MorsiThe Elephant In America's Newsrooms? Forbes. Available online. In: https://www.forbes.com/sites/richardbehar/2013/o1/11/newsflash-jews-are-apes-and-pigs-so-why-is-egypts-morsi-the-elephant-inamericas-newsrooms/\#136e5dec3ca2. Consultation date: 08/02/2020.

BENGEDALYAHU,Tzvi. 2012. Cairo Gov'tConceived in Violence, Bredin Chaos. Arutz Sheva. Available online. In: https://www.israelnationalnews.com/ News/News.aspx/157193. Consultation date: 08/02/2020.

CBC NEWS. 2013. World leaders put Egypt on notice over democracy. Available online. In: http://www.cbc.ca/news/world/world-leaders-put-egypton-notice-over-democracy-1.1347854. Consultation date: 08/02/2020.

ELECTION PROGRAM: THE FREEDOM AND JUSTICE PARTY. 2011. Parliamentary Election. Available online. In: http://kurzman.unc.edu/ files/2011/06/FJP_2011_English.pdf. Consultation date: 08/02/2020.

GAFUROV, Timur Vasilevich; SHIBANOVA, Natalia Aleksandrovna; PENKOVTSEV, Roman Vladimirovich. 2019. "The Nature of the Political Interaction between Israel and Saudi Arabia in the 21st Century" In: Journal of Politics and Law. Vol. 12, No. 5, pp. 53-56.

HABER, Joshua; IGHANI, Helia. 2013. A Delicate Balancing Act: Egyptian Foreign Policy After the Revolution. IMES CAPSTONE PAPER SERIES. Washington, USA.

KHIZRIYEV, Amirkhanovich Amirkhanov. 2016. "Egypt's domestic policy: 5 years after Tahrir's revolution" In: Problemy natsionalnoi strategii. Vol. 3, No. 36, pp. 6-63. (In Russian).

MIDDLE EAST. 2012. Israel and Hamas: Fire and Ceasefire in a New Middle East, International Crisis Group, 15. Report $\mathrm{N}^{\circ} 133$. Available online. In: https://www.crisisgroup.org/middle-east-north-africa/easternmediterranean/israelpalestine/israel-and-hamas-fire-and-ceasefirenew-middle-east. Consultation date: 08/02/2020.

MOKHOVA, Irina Mikhailovna. 2012. ThenewregimeinEgypt: Cantheforeignpolicybechanged?. Nezavisimaya Gazeta. Available online. In: http://www.ng.ru/courier/2012-10-01/9_egypt.html. Consultation date: 08/02/2020. (in Russian). 
PODTSEROB, Alexey Borisovich. 2017. "The impact of the Islamic factor on foreign policy of Islamic countries" In: Journal "Mezhdunarodnaya zhizn". Available online. Consultation date: 08/02/2020. (in Russian).

RAZHBADINOV, Marat Zaurovich. 2013. Theana to me of the Egyptian Revolution- 2011: Egypt before and after the political crisisin January-February 2011. - M.: The Institute of Oriental Studies of the Russian Academy of Sciences, 245-251. (In Russian).

SAPRONOVA, Marina Anatolyevna. 2013. Egypt: chaos, mess, confusion. MGIMO. Available online. In: https://mgimo.ru/about/news/ experts/240737/. Consultation date: 08/02/2020. (In Russian).

SHAGALOV, Vyacheslav Aleksandrovich; MANINA, Yulia Sergeevna. 2016. "Regional Security Problems in the North-East Africa" In: International Journal of Humanities and Cultural Studies (IJHCS). Vol. 1, No. 1, pp. 180-185.

SPENCER,Robert.2012.Egypt:IsraelplaysdownfearsoverMuslimBrotherhood" In: The Telegraph. Available online. In: http://www.telegraph.co.uk/ news/worldnews/africaandindianocean/egypt/9355273/Egypt-Israelplays-down-fears-over-Muslim-Brotherhood.html,. Consultation date: 08/02/2020.

STARKIN, Sergey Valerievich. 2012. "The main directions of Egypt's for eign policy: Regional aspect. S.V. Starkin” In: Istoricheskaya i sotsialnoobrazovatelnaya mysl. Vol. 6, No. 16, pp. 165-168 (in Russian).

THE GUARDIAN. 2012. Egypt-Israel border attack leaves over a dozen dead. Available online. In: https://www.theguardian.com/world/2012/ aug/o5/attack-across-egypt-israel-border. Consultation date: 08/02/2020.

THE NEW YORK TIMES. 2012. Israel and Hamas Agree to a Cease-Fire, After a U.S.-Egypt Push. Available online. In: http://www.nytimes. com/2012/11/22/world/middleeast/israel-gaza-conflict.htm. Consultation date: 08/02/2020.

THE NEW YORK TIMES. 2013. Ahmadinejad Visits Egypt, Signaling Realignment. Available online. In: http://www.nytimes. com/2013/o2/o6/world/middleeast/irans-president-visits-egypt-insign-of-thaw.html. Consultation date: 08/02/2020.

THE NEW YORK TIMES. 2013. Mohamed Morsi Comments On Jews 'Taken Out Of Context', Says Egypt Spokesman. Available online. In: http:// www.nytimes.com/2013/o1/17/world/middleeast/egypts-morsi- 
Ayrat Halitovich Tuhvatullin, Vitaly Anatolievich Epshteyn, Pavel Vladimirovich Pichygin y Alina Petrovna Sultanova

says-slurs-of-jews-were-taken-out-of-context.html. Consultation date: 08/02/2020.

THE NEW YORK TIMES. 2013. To Block Gaza Tunnels, Egypt Lets Sewage Flow. Available online. In: https://www.nytimes.com/2013/02/21/ world/middleeast/egypts-floods-smuggling-tunnels-to-gaza-withsewage.html. Consultation date: 08/02/2020.

THE TIMES OF ISRAEL. 2012. Abbas upset over Hamas-Egypt rapprochement. URL: Available online. In: http://www.timesofisrael.com/abbas-upsetwith-hamas-egypt-rapprochement/. Consultation date: 08/02/2020.

THE TIMES OF ISRAEL. 2012. Morsi denies sending friendly letter to Peres. Available online. In: https://www.timesofisrael.com/morsis-officedenies-egyptian-president-sent-letter-to-peres/. Consultation date: 08/02/2020.

THE TIMES OF ISRAEL. 2012. Morsi's office confirms warm letter to Peres is authentic. Available online. In: https://www.timesofisrael.com/morsisoffice-confirms-warm-letter-to-peres-is-authentic/. Consultation date: 08/02/2020.

THE TIMES OF ISRAEL. 2012. New Egyptian ambassador brings Israel 'message of peace. Available online. In: https://www.timesofisrael. com/new-egyptian-ambassador-brings-israel-a-message-of-peace/. Consultation date: 08/02/2020.

THE TIMES OF ISRAEL. 2013. Offensive remarks about Jews were taken out of context, Egypt's president insists during Germany visit. Available online. In: https://www.timesofisrael.com/morsi-anti-semitic-statementswere-taken-out-of-context/. Consultation date: 08/02/2020.

THE TIMES OF ISRAEL. 2013. The land of Palestine belongs to the Palestinians, not to the Zionists. Available online. In: https://www.timesofisrael. com/egypts-morsi-in-2010-statements-posted-online-called-zionistsbloodsuckers-and-descendants-of-pigs-urged-to-sever-all-ties-withisrael/. Consultation date: 08/02/2020.

THE WASHINGTON POST. 2012. Visit by Egypt's Morsi to Iran reflects foreign policy shift. Available online. In: https://www.washingtonpost. com/world/middle_east/visit-by-egypts-morsi-to-iran-reflects-foreignpolicy-shift/2012/o8/27/4baf4b3a-fo6o-11e1-b74c-84ed55eo3oob story.html?utm_term=.a01931f9e77a. Consultation date: 08/02/2020. 

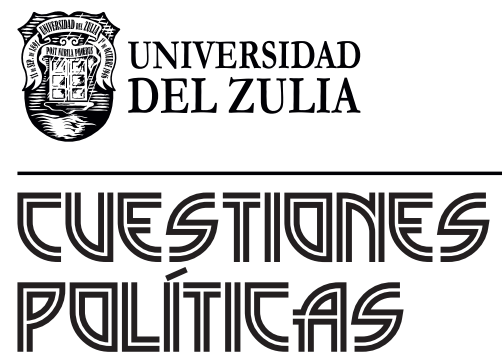

Vol.39 No 68

Esta revista fue editada en formato digital y publicada en enero de 2021, por el Fondo Editorial Serbiluz, Universidad del Zulia. Maracaibo-Venezuela 